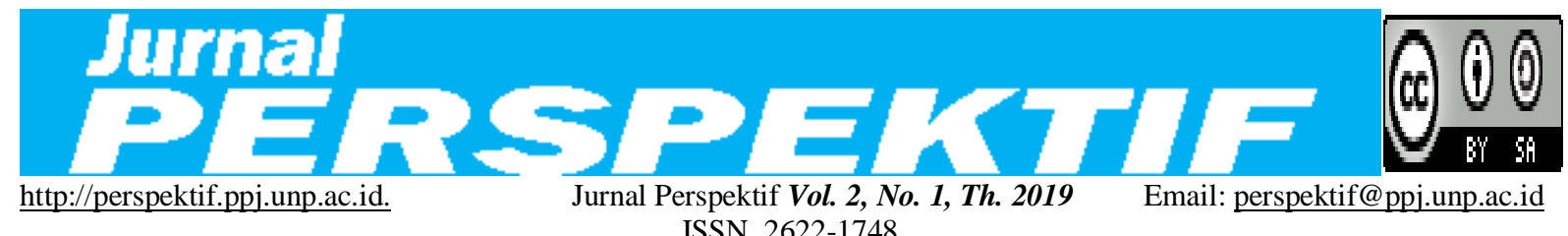
ISSN. 2622-1748

\title{
KEBERTAHANAN TAMBANG EMAS ILEGAL DI JORONG DURIAN SIMPAI NAGARI KOTO NAN IV DI BAWUAH KECAMATAN IX KOTO KABUPATEN DHARMASRAYA
}

\author{
Julianda Putri, Eka Vidya Putra \\ Universitas Negeri Padang \\ email: juliandaputri95@gmail.com, ekavidyaputra@gmail.com
}

\begin{abstract}
Abstrak
Penelitian ini mengkaji tentang kebertahan tambang emas ilegal di jorong Durian Simpai Nagari Koto Nan IV di Bawuah Kecamatan IX Koto Kabupaten Dharmasraya. Penelitian ini ini dianalisi dengan menggunakan teori strukturasi yang dikemukakan oleh Anthony Giddens. Penelitian ini menggunakan pendekatan kualitatif dengan tipe penelitian studi kasus intrinsik. Pemilihan informan dilakukan secara purposive sampling atau informan telah ditentukan dengan jumlah informan 15 orang. Pengumpulan data dilakukan dengan cara observasi non partisipatif, wawancara mendalam dan studi dokumentasi serta validitas data dilakukan dengan triangulasi data. Data yang diperoleh dianalisis dengan menggunakan analisis interaktif seperti yang dikembangkan oleh Miles dan Huberman dengan langkah-langkah pengumpulan data, reduksi, penyajian dan kesimpulan. Hasil penelitian dari kebertahanan tambang emas ilegal di Jorong Durian Simpai Nagari Koto Nan IV di Bawuah Kecamatan IX Koto Kabupaten Dhamasraya adalah; 1) adanya kerja sama yang dilakukan secara kerja sama internal dan kerja sama eksternal ,2) adanya membentuk kelompok, 3) adanya kontrak politik.
\end{abstract}

Kata kunci: Kebertahanan, Pertambangan (Tambang Emas.

Abstrack

This study examines the survival of illegal gold mines in Jorong Durian Simpai Nagari Koto Nan $I V$ in Bawuah Kecamatan IX Koto Regency Dharmasraya. This research was analyzed using structuration theory proposed by Anthony Giddens. This study uses a qualitative approach with an intrinsic case study type. The selection of informants was done by purposive sampling or informants were determined by the number of informants of 15 people. Data collection is done by non-participatory observation, in-depth interviews and documentation studies and data validity is done by data triangulation. The data obtained were analyzed using interactive analysis such as the one developed by Miles and Huberman with the steps of data collection, reduction, presentation and conclusion. The results of the study of the survival of illegal gold mines in Jorong Durian Simpai Nagari Koto Nan IV in Bawuah Kecamatan IX Koto, Dhamasraya Regency are; 1) the existence of cooperation carried out in internal cooperation and external cooperation, 2) the existence of forming groups, 3) the existence of political contracts.

Keywords: Defense, Mining (Gold Mine) 


\section{Pendahulan}

Jorong Durian Simpai merupakan salah satu jorong yang terdapat di Nagari Koto Nan IV di Bawuah Kecamatan IX Koto Kabupaten Dharmasraya. Masyarakat di Jorong itu dahulunya mayoritas bekerja sebagai petani perkebunan.Menurut historiografi masyarakat setempat, Jorong tersebut mayoritas terdiri dari daerah hutan yang tidak terpakai. Sekitar 15 tahun yang lalu seseorang berinisial Ex keturunan Jawa datang ke jorong tersebut. Dia melihat Jorong Durian Simpai ini memiliki potensi yang luar biasa, yaitu potensi emas di areal tanah yang dahulunya merupakan hutan yang tidak terpakai tersebut. Kemudian, Ex melakukan penambangan di satu daerah milik salah satu masyarakat setempat.

Dari kegiatan tambang yang dilakukan Ex, masyarakat melihat potensi tambang emas tersebut sangat menjanjikan. Hal itu ibarat pepatah minang maambiak contoh ka nan sudah, mancaliak tuah ka nan manang. Maksudnya iyalah mengambil contoh pada kejadian yang telah berlalu dan melihat kenyataan kepada yang menang. Hal tersebut dikaitkan dengan kenyataan tentang keuntungan yang diperoleh Ex sebelum dan sesudah melakukan tambang emas di daerah itu.

Berangkat dari kenyataan tersebut, masyarakat di Jorong Durian Simpai tertarik dan membuka lahan-lahan hutan mereka untuk turut mengikuti jejak Ex yaitu ikut melakukan penambangan di area mereka. Dari data dan informasi yang diperoleh terdapat 15 orang pemilik tambang di Jorong Durian Simpai. Adapun pemilik tambang tersebut yaitu: (1) RM 48 tahun, (2) JN 30 tahun, (3) LI 28 tahun, (4) HT 42 tahun, (5) BR 40 tahun, (6) UN 51 tahun, (7) Parno 40 tahun, (8) SL 55 tahun, (9) DT 31 tahun, (10) MD 52 tahun, (11) BG 55 tahun, (12) AS 40 tahun, (13) EH 44 tahun, (14) AT 50 tahun dan (15) SD 54 tahun.

Masing-masing pemilik tambang memiliki 15 (lima belas) hingga 50 (lima puluh) orang penambang. Hal tersebut sesuai dengan tingkat kesulitan penambangan.Pemilik tambang di jorong itu merupakan masyarakat setempat, sementara pekerja tambangnya merupakan pekerja yang didatangkan dari pulau Jawa. Terkait dengan penghasilannya, rata-rata satu tempat tambang berkisar lebih kurang Rp. 50.000.000,- (lima puluh juta rupiah) per minggu. Dari penghasilan tersebut akan dibagi menjadi tiga bagian, $40 \%$ untuk upah penambang, $40 \%$ untuk pemilik modal, dan $20 \%$ untuk pemilik lahan. Jika pemilik modal dan pemilik tambang merupakan orang yang sama, maka $60 \%$ menjadi miliknya.

Dibalik kenyataan penghasilan yang menjanjikan, ternyata dari semua tambang yang ada, tidak satupun mereka yang memiliki perizinan yang legal. Padahal jika kita merujupada Undang Undang Dasar 1945 pasal 33 ayat 3 menyatakan bahwa bumi dan air dan kekayaan alam yang terkandung di dalamnya dikuasai oleh negara dan dipergunakan untuk sebesar-besar kemakmuran rakyat. Pelaksanaan ketentuan pasal 33 ayat 3 ini diatur lebih lanjut dengan undang-undang dengan memperhatikan prinsip efisiensi dan berkeadilan.Selain itu penjelasan dari undang undang dasar tersebut menegaskan bahwa sumber-sumber yang ada harus dialokasikan secara efisien untuk mendukung perekonomian nasional secara sehat dan sekaligus mencapai keadilan.

Selain dalam UUD 45, terkait keberadaan tambang tersebut juga diatur dalam peraturan mentri energy dan sumberdaya mineral nomor 34 tahun 2017 tentang perizinan di bidang penambangan mineral dan batubara. Kemunculan peraturan mentri tersebut dilandasi oleh pertimbangan: (1) memberikan pedoman dalam penyelenggaraan pengusahaan di bidang pertambangan mineral dan batubara yang perlu mengatur ketentuan mengenai tata cara 
pemberian dan pelaksanaan perizinan di bidang pertambangan mineral dan batubara, (2) untuk mendorong pengembangan pengusahaan, menjamin kepastian hokum dan kepastian berusaha, dan meningkatkan efektifitas pemberian perizinan di bidang usaha pertambangan mineral dan batubara, perlu melakukan penyederhanaan perizinan di bidang pertambangan mineral dan bartubara, dan (3) berdasarkan pertimbangan sebagaimana dimaksud dalam huruf a, huruf b, dan untuk melasanakan ketentuan pasal 127 undang-undang nomor 4 tahun 2009 tentang pertambangan mineral dan batubara serta ketentuan pasal 27 ayat 2, pasal 41, pasal 44 ayat 5, pasal 68, dan pasal 83 peraturan pemerintah nomor 23 tahun 2010 tentang pelaksanaan kegiatan usaha pertambangan mineral dan batubara.

Hal tersebut menegaskan bahwa keberadaan tambang harus diikutsertakan dengan perizinan yang jelas, agar terdapat legalitas yang resmi dalamhal melakukan kegiatan usaha.Akan tetapi, faktanya di Jorong Durian Simpai Nagari Koto Nan IV di Bawuah Kecamatan IX Koto Kabupaten Dharmasraya. hal tersebut tidak ada.Lahan tambang di jorong tersebut tidak memiliki izin yang jelas, hal tersebut telah berlangsung bertahun-tahun yang lalu, bahkan tidak ada penanganan dari pihak pemerintah hingga sekarang.

PETI merupakan singkatan dari penambangan emas tanpa izin, yang merupakan usaha pertambangan yang dilakukan oleh perseorangan atau sekelompok orang dan usaha ini tidak memperoleh izin dari pemerintah sesuai dengan undang-undang yang berlaku. PETI ini diawali oleh keberadaan para penambang tradisional, yang kemudian berkembang secara besar besaran dengan menggunakan mekanis memodern.

Penambang tradisional menggunakan dulang kayu atau dulang plastik untuk mencari emas, sedangkan penambang modern menggunakan mesin yaitu mesin dompeng atau robbin. Manfaat pekerjaan ini untuk membantu perekonomian masyarakat dan dapat mengurangi tingkat pengangguran di desa tersebut, dimana dahulunyapekerjaan masyarakatdi sektor perkebunan atau pertanian, dengan adanya Pertambangan Emas Tanpa Izin (PETI) masyarakat sudah banyak ikut bekerja disitu.

Dewasa ini sudah banyak akademisi yang melakukan penelitian terutama tentang keberadaan tambang khususnya tambang emas. Ega Lestari (2014) ${ }^{1}$ meneliti tentang pilihanpilihan masyarakat Nagari Padang Sibusuk Kabupaten Sijunjung dalam pengalihfungsian lahan pertanian menjadi lahan tambang emas ilegal. Hasil penelitiannya menyimpulkan pilihan-pilihan masyarakat dapat digolongkan kedalam dua faktor. Adapun faktor tersebut: (1) faktor internal meliputi kepemilikan modal yang meliputi uang dan lahan, waktu dan tenaga; serta (2) faktor eksternal meliputi nilai jual emas yang tinggi, lingkungan fisik, dan lingkungan sosial.

Beberapa penelitian di atas menunjukan kajian-kajian tentang polemik keberadaan tambang emas sudah cukup banyak. Di dalam penelitian ini, peneliti ingin mengetahui Kenapa aktifitas tambang masih bisa berjalan di Jorong Durian Simpai Nagari Koto Nan IV di Bawuah Kecamatan IX Koto Kabupaten Dharmasraya padahal secara formal hal tersebut dilarang.

\footnotetext{
${ }^{1}$ Skripsi Padang. UNP 2014 yang berjudul "Tambang Emas di Lahan Sawah, (Studi Kasus: pilihanpilihan Masyarakat Nagari Padang Sibusuk, Kabupaten Sijunjung Dalam Pengalihfungsian Lahan Pertanian Menjadi Lahan Tambang Emas Ilegal"
} 


\section{Metodologi Penelitian}

Penelitian ini dilakukan di Jorong Durian Simpai Nagari Koto Nan IV di Bawuah Kecamatan IX Koto Kabupaten Dharmasraya. Penelitian ini menggunakan pendekatan kualitatif dengan tipe penelitian studi kasus intrinsik. Pemilihan informan dilakukan secara purposive sampling atau informan telah ditentukan dengan jumlah informan 16 orang. Pengumpulan data dilakukan dengan cara observasi non partisipatif, wawancara mendalam dan studi dokumentasi serta validitas data dilakukan dengan triangulasi data. Data yang diperoleh dianalisis dengan menggunakan analisis interaktif seperti yang dikembangkan oleh Miles dan Huberman dengan langkah-langkah pengumpulan data, reduksi, penyajian dan kesimpulan.

\section{Temuan dan Pembahasan}

Dari kegiatan tambang yang dilakukan Ex, masyarakat melihat potensi tambang emas tersebut sangat menjanjikan. Sehingga satu persatu bermunculanlah titik-titik pertambangan emas di Jorong Durian Simpai itu. Dari hasil penelitian yang dilakukan, keberadaan tambang tersebut bukanlah milik perorangan saja, melainkan terdapat beberapa agen yang terlibat dalam tiap tempat tambang. Titik tambang terdapat sistem yang dibentuk untuk terwujudnya atau terlaksananya pertambangan di daerah itu, seperti pemilik lahan, pemilik modal, dan pekerja.

Bila dikaitkan dengan konsep sosiologi agen tambang tersebut memiliki cara yang beranekaragam untuk mempertahankan tambang emas tersebut diantaranya:

Pertama, Keberadaan tambang muncul berkat kerjasama beberapa orang atau pihak dengan kesepakatan yang dibuat antara mereka. Hal itu disebabkan oleh adanya kondisi jika pemilik tanah atau lahan tambang mengalami keterbatasan dalam membuka titik tambang di tanahnya. Seperti yang kita ketahui, untuk membuka tempat tambang, dibutuhkan banyak perlengkapan tidak hanya lahan, melainkan juga perlengkapan-perlengkapan operasional lainnya seperti alat penggali, tempat pemisah batu, gelondong, biaya mobilisasi, hingga biaya operasional lainnya. Jika suatu lahan memiliki potensi tambang emas, namun sipemilik lahan tidak memiliki modal, maka dia membutuhkan bekerja sama dengan pihak lain, agar lahannya dapat dikelola dan dimanfaat untuk kemudian dibuka areal pertambangan emas di situ.

Kedua, Membentuk kelompok. Sebagai tambang emas yang tidak memiliki izin yang lengkap, para pemilik tambang, pemilik modal sangat rentan dengan ancaman razia atau pun penertiban oleh aparat berwenang. Mengatasi hal tersebut, mereka membentuk kelompok dengan sesama mereka. Seperti yang hasil wawancara yang peneliti lakukan, para pelaku tambang memiliki wadah komunikasi khusus menggunakan applikasi sosial media seperti whatsapp. Dalam group wahatsapp yang dibuat oleh para pelaku tambang, memiliki multifungsi. Maksudnya yaitu group tersebut digunakan untuk kepentingan seputaran bisnis tambang emas mereka. Diantaranya berbagi informasi mengenai teknologi tambang, perkembangan tambang, karyawan, harga upah pekerja, bahkan juga berkaitan dengan info seputar keamanan areal tambang mereka. Terlihat adanya komunikasi yang tercipta antar pelaku tambang emas di jorong Durian Simpai nagari koto nan 4 di bawuah kec IX Koto Dharmasraya ini. dengan adanya group yang mampu membangun komunikasi sesama mereka tersebut.

Ketiga, Kontrak politik.Strategi yang dilakukan pelaku tambang emas di nagari Durian simpai agar kegiatan tambang tersebut berjalan aman yaitu dengan membuat kontrak politik. 
Mereka menyeakati untuk sama-sama mendukung calon-calon petinggi daerah yang akan menduduki bangku kekuasaan. Syaratnya yaitu mereka yang akan duduk atau yang akan didudung memang yang bisa memperjuangkan serta melindungi keberadaan mereka.

\section{Penutup}

Penelitian ini secara keseluruhan membahas tentang kebertahanan tambang emas ilegal di Jorong Durian Simpai Nagari Koto Nan IV di Bawuah Kecamatan IX Koto Kabupaten Dharmasraya yang keberadaan tambang tersebut bertentangan dengan aturan pemerintahan tentang kawasan tambang.

\section{Daftar Pustaka}

Moleong, Lexy J. (2013). Metode Penelitian Kualitatif Edisi Revisi. Bandung: PT. Remaja Rosdakarya.

Saleng, Abrar. (2004). Hukum Pertambangan. Yogyakarta: UII Press.

Suriadi, A. (2008). Resistensi Masyarakat Dalam Pembangunan Infrastruktur Perdesaan. Jurnal Komunitas, Program Pascasarjana, Program Studi Sosiologi FISIP Universitas Indonesia, No. 3, Vol. 4, hal. 52-69. 